\title{
Types Of Legal Protection Of A Trademark (Service Mark) In Foreign Countries: The Example Of The Madrid System
}

\section{Yuldashov Abdumumin Abdugopirovich}

PhD in Law, Senior Lecturer, Department of Intellectual Property Law, Tashkent State University of Law, Tashkent, Uzbekistan.

E-mail: abdumuminyuldashev@gmail.com

Article History:Received:11 January 2021; Accepted: 27 February 2021; Published online: 5 April 2021

Abstract: The article examines the place of a trademark (service mark) in the economy, the importance of the Madrid Protocol regarding the ownership of a trademark, its registration abroad and advantages. The Madrid Agreement and the Madrid Protocol also include such important issues as the need to adopt these documents. The article also describes the procedure and practice of registering a trademark abroad through the Madrid system, and also provides statistics on trademarks that have been registered using this system in recent years on the example of countries and individual entities. Including the article also discusses warning signs aimed at preventing the use of trademarks without the permission of the copyright holder.

Keywords: trademark, service mark, Madrid system, World Intellectual Property Organization, Madrid monitor, well-known trademark

\section{Introduction}

Today, a significant part of the world economy consists of the export of national products. As you know, products and services are based on the popularity of their brand. For this reason, governments in many countries are actively working to support local producers who are recognized and highly valued by consumers for their brands. At the same time, it is especially important to ensure the protection of trademarks (brands) of manufacturers of competitive products in foreign countries. Today popular brands can be considered as the official symbol of the country (for example, Apple, Ferrari, Adidas, Samsung, Sony, etc.). Today, owning a brand suitable for your business has become one of the main criteria for any business entity. If we look at the statistics, In 2001, the number of filings for trademarks worldwide exceeded 2 million, and by 2016, this figure exceeded

7 million. According to the Law of the Republic of Uzbekistan dated August 30, 2001 No. 267-II "On Trademarks, Service Marks and Appellations of Origin of Goods", a trademark and a service mark are goods and services of one legal entity or individual to other legal entities. and individuals are duly registered marks to distinguish them from such goods. The law also contains a rule according to which marks can be registered as trademarks, according to which images, words, symbols of a certain shape and other symbols or their collective expression of any one color or different colors can be registered as trademarks. This is consistent with the provisions of Article 15 of the 1994 World Trade Organization Trade-Related Aspects of Intellectual Property Rights (TRIPS) [1].

\section{Research and Analysis}

The Law of the Republic of Uzbekistan "On Trademarks, Service Marks and Appellations of Origin of Goods" practically complies with the norms of the above international document. The main reason for this is that the law was developed in accordance with the requirements of the TRIPS agreement, the Memorandum on Uzbekistan's accession to the WTO was signed in 1998, and the main source was the process of harmonizing national legislation with international standards [2].

It is stipulated that the legal protection of a trademark is also regulated by international agreements. In particular, in accordance with article 6 (bis) of the Paris Convention for the Protection of Industrial Property (1883), there is a preferential treatment for well-known trademarks that are widely known among consumers as a result of active advertising and widespread use among the public falls into this category [3]. For example, the well-known company McDonald's promoted this brand in 1974-1979 spent \$ 57 million. Well-known trademarks are protected without registration, and in some countries such trademarks are subject to "legal protection" depending on their class of use (international classification of goods and services).

The establishment of legal protection in relation to a trademark allows its owner to use this mark. After all, the ownership of a trademark is an absolute right and its use is strictly prohibited by anyone other than those who are not authorized by the copyright holder. Transfer of a trademark to other persons only in accordance with the Law of the Republic of Uzbekistan dated August 30, 2001 No. 267-II "On Trademarks, Service Marks and Appellations of Origin of Goods" and by order of the Director of the State Patent Office. No. 48 of May 11, 2005. (Registered in the Ministry of Justice of the Republic of Uzbekistan on June 
17, 2005 No. 1481) "Agreement on the transfer of rights to inventions, utility models, industrial designs, selection full or partial transfer of topologies of integrated microcircuits, full or partial transfer of all property rights and execution of agreements on the transfer of ownership of the program, computer database".

The "movement" of a trademark can be limited only in the following cases:

- with a list (class) of goods and services specified in the certificate;

- with an expiration date.

- the territory of protected countries;

Another aspect of this problem is the question of how many businesses can easily and quickly protect their trademarks in foreign countries. In addition, many people want to register their brand in many countries around the world at the same time. Indeed, when we touched on the aspects of restricting trademark movement above, it was pointed out that it is restricted to registered countries.

\section{The attention of the state to the protection of trademarks and the benefits provided to business in this regard}

In turn, protecting local business brands abroad is a very important issue. In particular, at a meeting chaired by the President of the Republic of Uzbekistan Sh.Mirziyoyev on October 12, 2020 on measures to improve the intellectual property protection system, special attention was paid to the issue of international registration of domestic trademarks. It is noted that today only 72 brands of the country's industry are registered at the international level. This is a very low figure, which affects not only the economic potential of the country, but also international ratings and indices in the field of intellectual property. Following this meeting, the President of the Republic of Uzbekistan Sh.Mirziyoyev instructed the Ministry of Investments and Foreign Trade to increase the international registration of local brands, to support their entry into the international market.

On the issues raised at the meeting, Government Decree No.826 of December 31, 2020 approved the Regulation on the procedure for providing financial assistance to exporting organizations by the Export Promotion Agency under the Ministry of Investment and Foreign Trade. According to this provision, the Export Promotion Agency will now provide financial assistance to exporting organizations in registering domestic goods and brands (trademarks) with foreign authorities - 100 percent, but not more than 10 thousand US dollars per exporting organization.

It should be noted that in recent years, local businesses in Uzbekistan have been paying serious attention to the protection of their goods and services. In particular, 7217 trademark applications were filed in 2019, which is $13.7 \%$ more than 2018. Of these, 4319 are national and 2898 are international applications. The number of international applications also increased by $15.3 \%$ compared to 2018 [5].

Although the rules of the Paris Convention for the Protection of Industrial Property (1883) and the TRIPS Agreement (1994) contain general rules for the protection of trademarks, they do not address issues related to their international protection. For this reason, documents on the registration of marks in the international order were later adopted, based on the research of modern students (1891 and 1989).

Global procedures for the international registration of marks and the Madrid System

The Madrid system, governed by the 1989 Protocol to the Madrid Agreement Concerning the International Registration of Marks, is one of the most convenient means of ensuring the simultaneous protection of trademarks in foreign countries. The Madrid Agreement Concerning the International Registration of Trademarks, signed on April 14, 1891 must be included in the list of the above documents aimed at the international registration of trademarks.

Although, the Madrid Agreement reflected important aspects of the international registration of trademarks, its rules did not reflect the requirements of many countries. This is why many countries, mainly European ones, have proposed creating a more effective legal framework. As a result, with the support of the World Intellectual Property Organization (WIPO), the 1989 Madrid Protocol was adopted. In general, the Madrid Agreement and the Madrid Protocol are also aimed at creating and improving the international registration of trademarks in addition to existing national systems. These international documents do not contain norms aimed at regulating the protection of well-known trademarks. The differences between the two documents are reflected in the procedures (procedures) related to the term of protection, the extension of the refusal period, registration fees and the official languages in which the proceedings are conducted. [6]

Likewise, a number of international unions have launched various systems for the simultaneous registration of trademarks on the territory of their member states. In particular, trademark owners in countries of the European Community may register their brands throughout the Community through the Community trademark system [7].

The Madrid System provides trademark owners with legal protection for their trademarks in member states of the Madrid Protocol to the Treaty on the International Registration of Marks by filing a single application with the competent intellectual property authority (trademark) in their territory. The system also 
provides copyright holders with a number of conveniences in managing their trademarks in particular, this aspect is manifested in the process of making any future changes or extensions to trademarks registered in the same application. The Madrid System is administered by the International Bureau of WIPO.

Based on the above, the Madrid System is one of the most convenient and effective mechanisms for registering and managing brands worldwide. This is the only centralized system that provides protection in the territory of the participating countries through a single application and customs duty, which allows you to change the global "portfolio" of trademarks, i.e. extend deadlines and expand geography.

\section{International and National Statistics (Uzbekistan) of the Madrid System}

In recent years, Uzbekistan has given serious attention to the process of legal protection of trademarks by both local organizations and non-residents. According to the indicators of trademarks of the WIPO for 2017, Uzbekistan is one of the three leaders in the ranking of countries with moderately developed economies with an annual growth rate of $12-14 \%$. However, in the countries included in this rating, there are many cases where businesses are often limited to providing legal protection to brands in their countries [8].

It should be noted that from year to year in Uzbekistan, the statistics of registration of their trademarks by foreign applicants under the Madrid system is growing. Our country joined the Protocol to the Madrid Agreement on the International Registration of Marks by Law No. 40 dated July 18, 2006. It should be noted that this international document is the last document in the field of intellectual property, to which Uzbekistan joined until 2018.

Table

Number of applications for registration of the Madrid System trademark in Uzbekistan (by years)

\begin{tabular}{|c|c|c|c|c|c|}
\hline 2015 year & 2016 year & 2017 year & 2018 year & 2019 year & Total \\
\hline 2715 & 1960 & 2387 & 2513 & 2898 & 12473 \\
\hline
\end{tabular}

This system is available to citizens of 123 participating countries. The cost of registering a trademark using the Madrid system includes the base fee (653 Swiss francs, 903 Swiss francs if the symbols are colored) and the cost of protecting the mark, the number of classes according to the international classification of goods and Services. A number of countries are also introducing the use of an integrated system for the payment of patent fees through the Madrid System. For example, from 16 February 2018, registration of an unpainted trademark in India and the European Union will cost a total of CHF 1,698 per class (base fee 653 CHF, 148 CHF per class (India), 897 CHF per class (European Union). An international application is first filed with the local intellectual property authority, which sends the documents to the WIPO International Bureau. It is important to note that the Madrid System is much more user-friendly by WIPO, that is, the user has the ability to track the status of the application in the Real Time Status section of a system called Madrid Monitor.

There is also the WIPO Global Brand Database, which contains 55 national and international information bases which registered brands. This database contains information on brands registered under the Madrid Agreement, therefore this database is an important resource when looking for similar and identical brands.

The WIPO International Bureau requests by notification the international registration of the mark in question in each country named in the application. In turn, countries may refuse to register a trademark requested for protection in full (for all goods and services specified in the application) or partially (for a certain part of the goods and services specified in the application). The country concerned notifies the International Bureau of WIPO, and the International Bureau notifies the competent authority of the said state and the applicant.

If the application meets the requirements of the Madrid System (as well as the payment of certain international fees), the International Bureau enters the mark in the international register, registers the mark internationally, publishes the information on the international registration in the official gazette (WIPO Gazette of International Marks) and sends the owner a certificate of international registration.

According to the requirements of the Madrid System, an international application must be in one of the English, French or Spanish languages. When using this system, a single customs fee is also charged. In this system, there are also no requirements for the services of patent attorneys, since the WIPO International Bureau itself receives applications and sends them to the respective countries. All of the above will reduce costs for patent attorneys, translators and filing fees. The period for consideration of an application filed through the Madrid system is 18 months, and the period for its protection, as usual, is 10 years, and the copyright holder can again extend this period by paying the appropriate fee.

The main advantage of using this system is that it does not require time and additional effort, i.e. the interested company can ensure its protection in the territory of the selected countries with the help of one 
application. Another advantage of the Madrid System is the low use of costly resources, i.e. if a company strives to solve all problems with one application, it means that there is no need for patent attorneys and no overpayments.

The number of applications filed through the Madrid System in 2016 was 59,493 worldwide, an increase of $9.1 \%$ compared to 2015. The USA (7730), Germany (7544), France (4124) and China (3820) are leading in the ranking of applications through this international system. Chinese applicants filed 1,860 more applications in 2016 than in 2015, which is $94.7 \%$ more, moving up from 9 th to 4 th place in the ranking [9].

If we look at the statistics for 2019, the number of applications filed through this system has grown to 64,400, while the United States is still in the lead (1,261). Switzerland (344) and Turkey (543) also saw strong growth this year. In 2019, leading countries of the world such as Canada, Brazil and Malaysia joined the system. In general, the countries those are part of the Madrid system today account for $63 \%$ of the world's population, $80 \%$ of the population and $87 \%$ of world GDP [10]. In general, the number of cases of registration of trademarks using this system is growing from year to year.

Among the companies that registered their brands in 2019 using this system, L'Oréal (France) filed 189 applications, Novartis AG (Switzerland) filed 135 applications, Huawei Technologies (China) filed 131 applications and NirSan Connect (India) filed 124 applications. Applications lead with it is noteworthy that the number of Asian companies presenting their brands through the Madrid system is growing every year. In particular, 6 companies in the top 20 list belong to the Asian continent. If we take the top 100 companies, then $64 \%$ - in Europe, $18 \%$ - in North America (mainly the USA), 15\% - in Asia. These companies also submitted 4,100 applications, which is $6 \%$ of the total number of applications.

\section{Aspects of the Madrid System (positive and negative)}

Researcher Agnieszka Przygoda focused on the positive and negative of the Madrid System in her research work.

Advantages.

1) Single Application. The main advantage of this system is that trademark owners are exempt from the obligation to file applications separately for each jurisdiction. When applying, you must complete the uniform MM2 form, excluding the national forms. This application form should be submitted directly to the National Intellectual Property Office and not to WIPO. This frees trademark owners from having to register, translate, and pay patent fees in each state's language. Based on the results of the preliminary examination, except in cases of rejection of the application, there is no obligation to correspond with the National Office of Foreign Intellectual Property. In addition, a positive decision will be taken if no state responds to the application after 18 months from the date of filing.

2) Cost-effective. The Madrid System provides effective trademark protection in many markets. The link with many national programs through a single system is in practice the greatest achievement of the Madrid System. The use of such a system is usually chosen by transnational corporations (TNCs) that want to protect their brands around the world. WIPO and the State requesting the trademark receive a fee for their services and processing of the international application. In this case, the applicant must pay WIPO 2 and in some cases the following 3 separate fees.

- Basic payment;

- A separate payment for each country requesting protection;

- Surcharge if more than 3 classes are selected according to the International Classification of Goods and Services (Nice Classification).

The EU and the UK have agreed to receive the last 2 payments in one payment. For example, an applicant wishing to register his mark in the European Union must pay a single standard fee of 850 euros, and if he chooses the Russian Federation, he will have to pay an additional 100 Swiss francs. In practice, the local authorities to whom the initial application is submitted also charge a fee for the "processing" of documents. Based on the above, the Madrid system is the most cost-effective for the applicant.

3) Centralized Administration. After the mark is included in the international register, its owner will be able to manage it through a single centralized WIPO system (WIPO, How to manage your International Registration: Overview, 2019). In this case, the copyright holder can change, update the brand, or expand its "business areas" with a single request. Term of international protection having established 10 years, the copyright holder can extend them for another 10 years. At the same time, the extension of the term of protection of a trademark through a one-time payment has been recognized as one of the greatest achievements.

In this system, you can also change the name and address of the owner of the trademark or transfer the rights to it to others. However, registration of a license in the international register does not apply to all countries in the same way. For example, registration of a license in the international registry is not valid in Japan. For this reason, it is always recommended to take into account the national requirements set out in the register. 
Disadvantages.

1) Central attack. In this case, if the local "source of trademark" mark has not been used for 5 years, revocation of that mark at the request of a third party may result in its cancellation of registration in the other country (s). This principle is called central attack.

2) "House brand" requirement. The person applying to register a trademark in the Madrid system or the person applying to register it:

- A party to the Madrid Protocol;

- Residence on the territory of a state party to the Madrid Protocol;

- It is required to be the owner of an industrial or commercial organization existing in the territory of a state party to the Madrid Protocol.

The above reasons can also be a problem for applicants or those who have just started their activities or have not yet started their activities in the field of membership [12].

In general, the degree of legal protection of intellectual property plays an important role in the innovative and economic development of the country. The role and place of intangible assets in modern economic relations are increasing [13].

\section{Conclusion}

In accordance with the above, ensuring the protection of a trademark, like all intellectual property objects, is an important issue. In particular, the authorities should pay more attention to making local businesses more accountable in this regard [14]. Local businesses and artisans need to have their own 'logo' to enhance the quality and visibility of their products.

Here it is necessary to dwell on the warning signs that the trademark has legal protection. In the legislation of many countries there is a process of warning labeling (marking) of products, which is aimed at drawing attention to the registered mark and preventing infringement. This marking can be in the form of the Latin letter R or the letter R, enclosed in a circle with the words "trade mark" or "registered mark". In world practice, in addition to the above warning words, the words TM or Trademark are used, as well as the words "Registered Trademark" (Great Britain), "Marfue deposee" (France, Belgium), "Marks Registrada" (Latin America) are also used. According to the Law of the Republic of Uzbekistan "On Trademarks, Service Marks and Appellations of Origin of Goods", the owner of a trademark or certificate of the right to use an appellation of origin together with a trademark or an appellation of origin and a warning sign in the form of a letter " $R$ " in the Latin alphabet or circle " $R$ " indicating that the mark used on the package is a trademark registered in Uzbekistan or the name of the place of origin of goods.

Based on the above, measures need to be taken to ensure legal protection of trademarks abroad, to support domestic producers and service providers in the Madrid System, and to strengthen advocacy in this area to convey its benefits.

\section{References}

1. Соглашение по торговым аспектам прав интеллектуальной собственности. Available at: https://www.wipo.int/edocs/lexdocs/treaties/ru/wto01/trt_wto01_001ru.pdf.

2. Working Party on the Accession of Uzbekistan. Available at: https://www.wto.org/english/thewto_e/acc_e/a1_ouzbekistan_e.htm\#status

3. Парижская конвенция по охране промышленной собственности (измененная 28 сентября 1979 г.). Available at: https://wipolex.wipo.int/ru/text/379398

Интеллектуал мулк объектларини мухофаза қилиш масалалари мухокама қилинди. Available at: https://president.uz/uz/lists/view/3887

4. Агентство по интеллектуальной собственности при Министерстве юстиции Республики Узбекистан. Годовой отчет 2019.2 Available http://ima.uz/upload/doc/\%D0\%B3\%D0\%BE\%D0\%B4\%20\%D0\%BE\%D1\%82\%D1\%87\%D0\%B5\%D 1\%82-2019 c.pdf.

5. Phan Ngoc, Tam. Well-known trademark protection. A comparative study between the laws of the European Union and Vietnam. Field of study: International and Comparative law Code: 62.38.60.01. The Faculty of Law, Lund University. Doctoral dissertation of law. Hochiminh city. 2011.

6. Mirësi Çela. The importance of Trademarks and a review of empirical studies. European Journal of Sustainable Development (2015), 4, 3, 125-134. ISSN: 2239-5938. Doi: 10.14207/ejsd.2015.v4n3p125.

7. World Intellectual Property Indicators 2017 Trademarks [WIPO Statistics Database, September 2017]. Available at: https://www.wipo.int/edocs/pubdocs/en/wipo_pub_941_2017-chapter3.pdf 
8. World Intellectual Property Indicators 2017 Trademarks [WIPO Statistics Database, September 2017]. Available at: https://www.wipo.int/edocs/pubdocs/en/wipo_pub 941_2017-chapter3.pdf

9. Madrid Yearly Review 2019. International Registration of Marks. WIPO, 2019. Available at: https://www.wipo.int/edocs/pubdocs/en/wipo_pub_940_2019.pdf

10. Madrid Yearly Review 2019. International Registration of Marks. WIPO, 2019. Available at: https://www.wipo.int/edocs/pubdocs/en/wipo_pub_940_2019.pdf

11. Agnieszka Przygoda. "The International Registration of Trade Marks under the Madrid System: Advantages and Disadvantages". Eastern European journal of transnational relations 2019 Vol. 3 No. 1 DOI: 10.15290/eejtr.2019.03.01.05. British American Tobacco, London, United Kingdom.

12. Юлдашов А., Чориев М. (2020) “Договорно-правовые отношения в области авторского права и ответственности за нарушение авторского права: национальный и зарубежный опыт”. Общество и инновации. Выпуск 1 № 1/s . 511-522. doi.org/10.47689/2181-1415-vol1-iss1/s-pp511-522

13. Mokhinur, Bakhramova. "A THOROUGH REVIEW OF THE COMMON LAW CONCEPT OF" ARBITRARY TERMINATION" AND" UNFAIR DISMISSAL"(including DIFC\&ADGM." Review of law sciences NOVEMBER (2020). https://scholar.google.com/citations?user=oTxyzXYAAAAJ\&hl=en 